\title{
Carapace length-weight and width-weight relationships of Scylla serrata in Bulungan District, North Kalimantan, Indonesia
}

\author{
BAMBANG WIDIGDO $^{1, \boldsymbol{\vartheta}}$, RUKISAH ${ }^{2}$, ASBAR LAGA ${ }^{2}$, AGUS A. HAKIM ${ }^{1}$, YUSLI WARDIATNO $^{1}$ \\ ${ }^{1}$ Department of Aquatic Resources Management, Faculty of Fisheries and Marine Sciences, Institut Pertanian Bogor. Jl. Raya Darmaga, Kampus IPB, \\ Bogor 16680, West Java, Indonesia. Tel./Fax. +62-251-8622932, "email: bbg_widigdo@yahoo.co.id \\ ${ }^{2}$ Faculty of Fisheries and Marine Sciences, Universitas Borneo Tarakan. Jl Amal Lama No 1, Tarakan 77123, North Kalimantan, Indonesia
}

Manuscript received: 8 July 2017. Revision accepted: 22 August 2017.

\begin{abstract}
Widigdo B, Rukisah, Laga A, Hakim AA, Wardiatno Y. 2017. Carapace length-weight and width-weight relationships of Scylla serrata in Bulungan District, North Kalimantan, Indonesia. Biodiversitas 18: 1316-1323. The mud crab, Scylla serrata lives associated with mangrove ecosystems and is widely distributed in the Indo West-Pacific. The present work was aimed to reveal the carapace length/width-weight relationships of Scylla serrata in two mangrove ecosystem area of Bulungan District, North KalimantanIndonesia, i.e. Kahayan Delta and Tibi Island. The crabs were collected by using ambau pancang (trap) for two months from November to December 2016. A total of 522 individuals were collected and their carapace length, carapace width, and weight were measured. The sex ratio of total collected samples (male to female) was 1:0.79. Carapace length and width of $S$. serrata caught in these two study area ranged from 40 to $89 \mathrm{~mm}$ for male; 32 to $91 \mathrm{~mm}$ for female and 59 to $128 \mathrm{~mm}$ for male; 53 to $122 \mathrm{~mm}$ for female, respectively. The carapace length-weight relationships of total samples showed logarithmic equations as follow: $\mathrm{W}=-3.2194+2.9725 \mathrm{Log}$ CL for male and $\log \mathrm{W}=-2.2010+2.3750 \mathrm{Log} \mathrm{CL}$ for female. While the carapace width-weight relationships are as follow: $\mathrm{W}=-3.9162+3.1012$ $\log \mathrm{CW}$ for male and $\log \mathrm{W}=-2.6001+2.3968 \mathrm{Log} \mathrm{CW}$ for female. The $\mathrm{b}$ values of carapace width-weight relationship indicated that the growth pattern of male was positive allometric and female was negative allometric. Size frequency of crab population is also presented.
\end{abstract}

Keywords: Allometric relationship, crustacea, growth pattern, mangrove, mud crab

\section{INTRODUCTION}

The mud crab, Scylla serrata is known to live associated with mangrove ecosystems and is widely distributed in the Indo West-Pacific. The mud crab is a nocturnal organism and is mostly burrowing during low tide (Hill 1976; Barnes et al. 2002), but they will be very active to forage when the habitat is covered by seawater at high tide (Nirmale et al. 2012). The crab is abundant in estuaries and swamps water with dense of mangrove vegetation (Keenan et al. 1998; Barnes et al. 2002). Genus Scylla is a commercially important species of the Indonesian crustaceans and has become a high economic value commodity (Cholik 2005). Increasing of the mangrove crabs demand can threaten existence of the population. So, the biological information is needed as a basis for utilization and management of mud crab resources.

One of potential location to catch mud crabs is mangrove ecosystem in Bulungan District, North Kalimantan-Indonesia. The ecosystem is located between $2^{\circ} 26.5^{\prime}-3^{\circ} 45^{\prime}$ North latitude and $117^{\circ} 18^{\prime}-117^{\circ} 58^{\prime}$ East longitude. The local fishermen catch the crab by using a local trap, so-called ambau pancang. Up to now, there were only a few researches on mud crab of North Kalimantan, e.g. resource potential (Natanael and Wiharyanto 2016), meroplankton of Scylla sp. (Triana and Wiharyanto 2016), and reproductive biology (Farizah 2011; Iromo et al. 2013; Iromo and Farizah 2014).

The study of carapace width-weight relationships assumes an important prerequisite in biology, physiology and ecology (Froese 2006; Mohapatra et al. 2010; Thirunavukkarasu and Shanmugam 2011). The estimation is useful to determine the variations in expected weight from the known length groups which are one after another the indication of size, reproduction and nourishing states (Gayathre et al. 2016). Application of this study for aquatic animals has done in delineating the growth patterns during their developmental pathways (Bagenal 1978). Information about individual carapace width-weight relationship is important to estimate the population size or stock structure (Josileen 2011) and to use the stock assessment model (Moutopolos and Stergiou 2002). Some crustacean research used the carapace width-weight relationship as more suitable for evaluating populations (Atar and Sector 2003; Gorce et al. 2006, Sangun et al. 2009). The present work was aimed to reveal the carapace width-body weight relationship of mangrove mud crab (Scylla serrata) in two area of mangrove ecosystem in Bulungan District, North Kalimantan, Indonesia. The result is compared with the different population of the same species in other locations. 


\section{MATERIALS AND METHODS}

\section{Study site and sampling methods}

The samples were collected on November until December 2016 from Kahayan Delta and Tibi Island, Bulungan District, North Kalimantan Province, Indonesia (Figure 1). Totally 522 samples were caught using ambau pancang (local name) by fishermen. The specimens were transported to the laboratory for identification and measurement of carapace width and weight. Identification of species was based on FAO book identification $(\mathrm{Ng}$ 1998) and Keenan et al. (1998). Carapace Length (CL) was taken as the distance between the tips of the posterior most lateral carapace spines. Carapace Width (CW) was measured dorsally along the midline, between the frontal notch and the posterior margin of the carapace (Josileen 2011). Individual crab weight (W) was measured by digital scales. All samples were analyzed in fresh condition (living crabs).

\section{Data analysis}

The sex ratio was calculated using the formula: total number of males $\left(\sum \mathrm{M}\right)$ /total number of females $\left(\sum \mathrm{F}\right)$. The ratio was tested to see if it differs from a 50/50 ratio by Chi-Square test (Steel and Torrie 1980). The carapace length/width-weight relationship was estimated using the exponential equation $\mathrm{W}=\mathrm{aL}^{\mathrm{b}}$ (Ricker 1975). The exponential equation was transformed to logarithmic equation $\log \mathrm{W}=\log \mathrm{a}+\mathrm{b} \log \mathrm{L}$, where $\mathrm{W}=$ weight, $\mathrm{L}=$ carapace width, $a=$ ' $y$ '-intercept and $b=$ the slope or growth coefficient. The R-squared was determined to identify the association degree of two variables. Growth pattern was determined by value of growth coefficient (b value). The pattern was defined as follows: isometric growth $(b=3)$, or positive allometric $(b>3)$ or negative allometric $(b<3)$. The differences of the carapace widthweight relationship between sexes were tested by one-way ANOVA at $\mathrm{p}=0.05$.

\section{RESULTS AND DISCUSSION}

\section{Results}

A total of 522 mud crabs were sampled in two locations, 291 samples from Kahayan Delta and 231 samples from Tibi Island. The sex of mud crabs was determined in accordance to Keenan et al. (1998) and showed in Figure 2. The shape of the abdomen or tail flat is a thin triangular apron for males, while the female's is larger.

Sex ratios of male to female of total collected sample and each location (Kahayan Delta and Tibi Island) were 1:0.79, 1:0.82 and 1:0.76, respectively. Chi-Square test of sex indicated a significantly different $(p<0.05)$, meaning that the population was not in balance between of the number on male and female crab the two locations. Detail information of the sex ration at the two location is presented in Table 1.

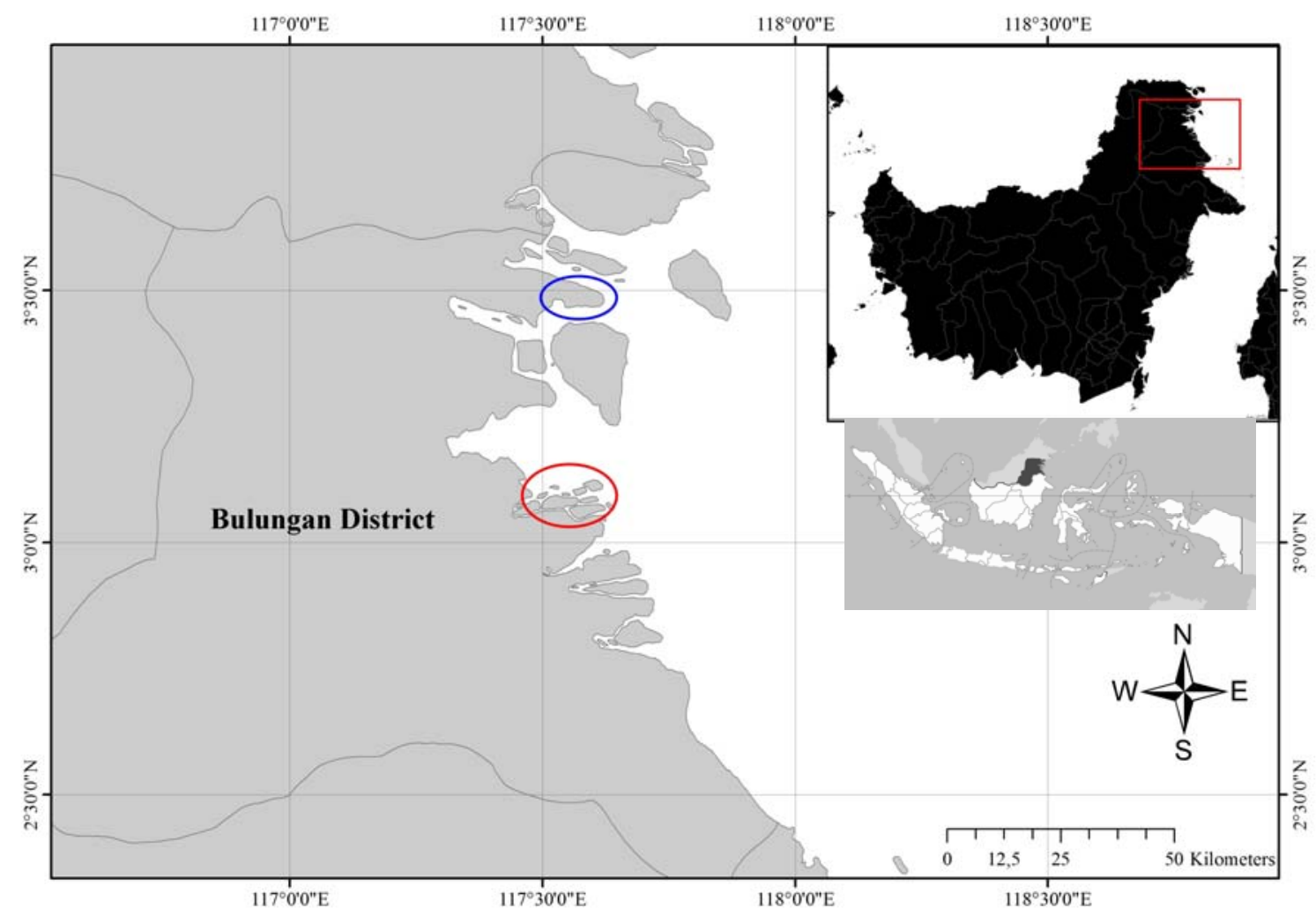

Figure 1. Locations where the mud crabs were collected. The red ellipse indicates Kahayan Delta and the blue ellipse indicates Tibi Island, Bulungan District, North Kalimantan, Indonesia 

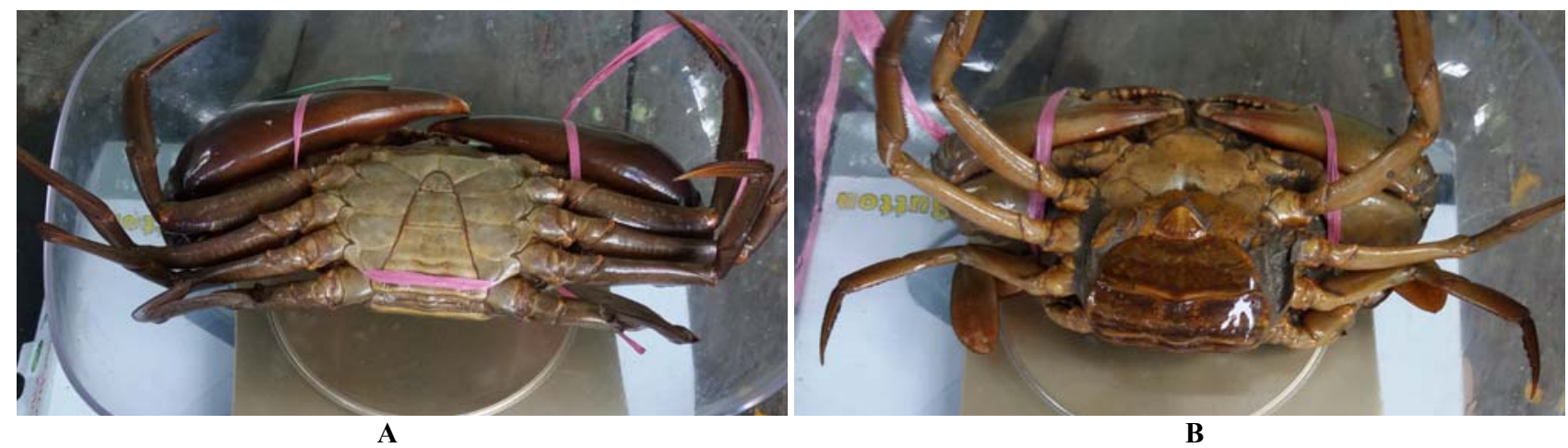

Figure 2. Sex of mud crabs (A) male, (B) female. The shape of the abdomen or tail flat is a thin triangular apron for males, while the females is larger

Tabel 1. Sex ratio of Scylla serrata from Bulungan District, North Kalimantan, Indonesia

\begin{tabular}{|c|c|c|c|c|c|c|c|}
\hline \multirow{2}{*}{ Location } & \multirow{2}{*}{ Sex } & \multirow{2}{*}{ Number of samples } & \multicolumn{2}{|c|}{ Carapace Length (mm) } & \multicolumn{2}{|c|}{ Carapace Width (mm) } & \multirow{2}{*}{ Sex ratio } \\
\hline & & & Min & Max & Min & Max & \\
\hline \multirow[t]{2}{*}{ Total } & Male & 291 & 40 & 89 & 59 & 128 & 1: 0.79 \\
\hline & Female & 231 & 32 & 91 & 53 & 122 & \\
\hline \multirow[t]{2}{*}{ Kahayan Delta } & Male & 159 & 40 & 89 & 59 & 128 & 1: 0.82 \\
\hline & Female & 131 & 32 & 89 & 53 & 122 & \\
\hline \multirow[t]{2}{*}{ Tibi Island } & Male & 132 & 40 & 87 & 62 & 127 & 1: 0.76 \\
\hline & Female & 100 & 43 & 91 & 61 & 122 & \\
\hline
\end{tabular}

In total carapace length of $S$. serrata caught in the two study area ranged from 40 to $89 \mathrm{~mm}$ for male and 32 to 91 $\mathrm{mm}$ for female. In terms of location, the carapace length of the crab ranged from 32 to $89 \mathrm{~mm}$ in Kahayan Delta and 40 to $91 \mathrm{~mm}$ in Tibi Island (Table 1). The minimum size of carapace length was found in Kahayan Delta and the maximum size was found in Tibi Island. Size frequency distribution of carapace length is shown in Figure 3. Based on the figures, male and female crabs exhibited some size variation. The maximum size of S. serrata was found in 84$89 \mathrm{~mm} \mathrm{CL}$ for male and 90-95 mm CL for female. No male was found with carapace length more than $89 \mathrm{~mm}$. The situation is the same with Tibi Island, but different with Kahayan Delta. In Kahayan Delta, no male and female were found more than $89 \mathrm{~mm}$. The dominant size of $S$. serrata in total, Kahayan Delta, and Tibi Island were found 60-65 mm for male and 54-59 $\mathrm{mm}$ for female.

Carapace width of $S$. serrata caught in the two study area ranged from 59 to $128 \mathrm{~mm}$ in male and 53 to $122 \mathrm{~mm}$ in female. While, the carapace width ranged from 53 to 128 $\mathrm{mm}$ in Kahayan Delta and 61 to $127 \mathrm{~mm}$ in Tibi Island (Table 1). The minimum and maximum size of carapace width were found in Kahayan Delta. Size frequency distribution of carapace width is shown in Figure 4. Base on the figure, male and female crabs exhibited some size variation. The maximum size group of $S$. serrata was found in 127-133 mm CW for male and 120-126 mm CW for female. No female was found with carapace width more than $133 \mathrm{~mm}$. The condition occurred in both locations. The dominant size of $S$. serrata in total, Kahayan Delta, and Tibi Island were $92-98 \mathrm{~mm}$ for male, but it was not the case for female. The total and Kahayan Delta for female were dominated by $78-84 \mathrm{~mm}$ sizes, but it was $71-77 \mathrm{~mm}$ in Tibi Island.

A Scatter diagram was composed by plotting logarithm of carapace length/width against logarithm of weight of individual crabs (Figure 5 and Figure 6). The logarithmic equation $\log \mathrm{W}=\log \mathrm{a}+\mathrm{b} \log \mathrm{L}$ was used to estimated carapace length/width-weight relationship of mud crabs. The carapace length-weight relationship results of total showed logarithmic equations are as follows: $\mathrm{W}=-3.2194$ $+2.9725 \log$ CL for male and $\log \mathrm{W}=-2.2010+2.3750$ Log CL for female. While, the result of carapace Lengthweight relationship in Kahayan Delta and Tibi Island are$3.0117+2.8570 \log \mathrm{CL}$ for male and $\log \mathrm{W}=-1.9701+$ 2.2455 Log CL for female, and $\log \mathrm{W}=-3.4634+3.1081$ $\log \mathrm{CL}$ for male and $\log \mathrm{W}=-2.6013+2.6017 \mathrm{Log} \mathrm{CL}$ for female. The R-squared obtained for the carapace length and weight of males and females were nearly equal to 1 (0.83-0.91). The value indicated a high degree of positive correlation of length and weight for male and female crabs. 


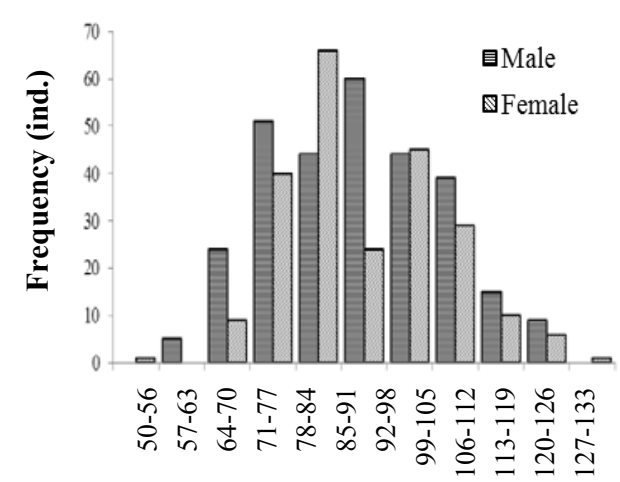

CL size group

$\mathbf{A}$

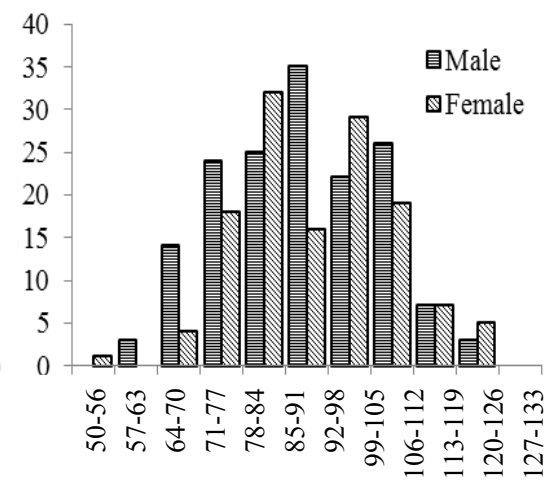

CL size group

B

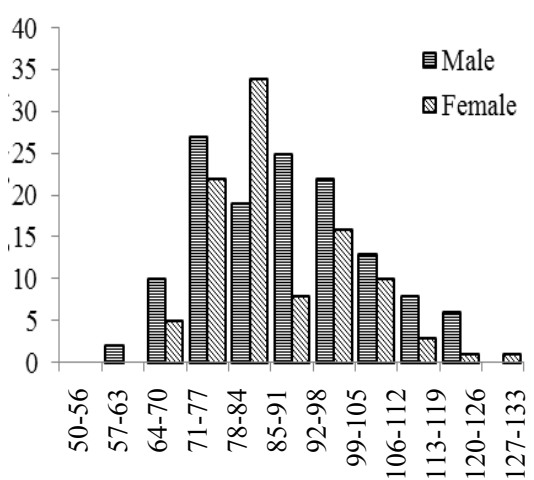

CL size group

C

Figure 3. Size frequency distribution of carapace length of Scylla serrata in different location (A) total, (B) Kahayan delta, (C) Tibi island, Bulungan District, North Kalimantan, Indonesia

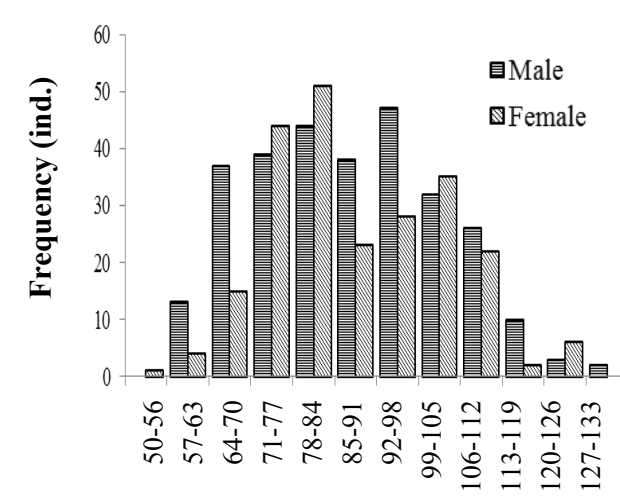

CW size group

A

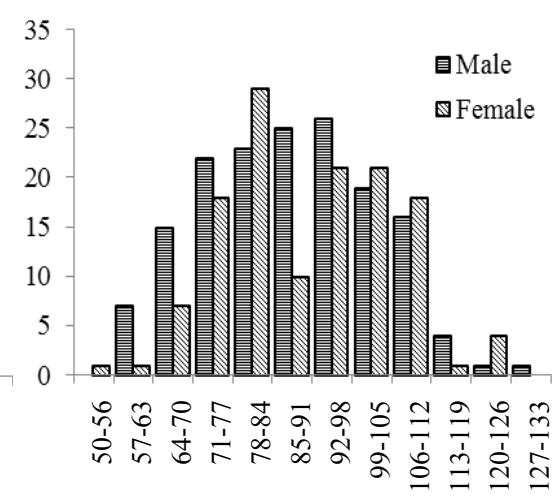

CW size group

B

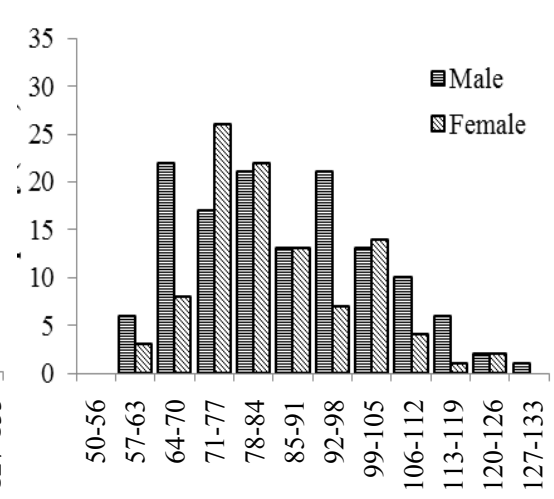

CW size group

C

Figure 4. Size frequency distribution of carapace width of Scylla serrata in different location (A) total, (B) Kahayan Delta, (C) Tibi Island, Bulungan District, North Kalimantan, Indonesia

The carapace width-weight relationship results of total showed logarithmic equations are as follows: $\mathrm{W}=-3.9162$ $+3.1012 \log \mathrm{CW}$ for male and $\log \mathrm{W}=-2.6001+2.3968$ Log CW for female. While, the result of carapace widthweight relationship in Kahayan Delta and Tibi Island are$3.6917+2.9809 \log \mathrm{CW}$ for male and $\log \mathrm{W}=-2.6134+$ 2.3982 Log CW for female, and $\log W=-4.1882+3.2474$ Log CW for male and $\log W=-2.7538+2.4840 \log C W$ for female. The R-squared obtained for the carapace width, and weight of males and females were nearly equal to 1 (0.86-0.92). The value indicated a high degree of positive correlation of width-weight for both sexes.

The growth pattern was estimated by $b$ value from carapace width-weight relationship. The growth coefficient values (b) of male and female width-weight were 3.1012 and 2.3968. Based on the values, we found $b$ value more than 3 for male indicating a positive allometric. It means the increase of weight is faster than the increase of carapace width. But, it was not the case in female with $b$ value less than 3 . The value indicates negative allometric of growth pattern. The $\mathrm{b}$ values were different between male and female crab (ANOVA, $\mathrm{P}<0.05$ ).

\section{Discussion}

The information on sex ratio is important in the interpretation of the population structure and reproductive performance in crustaceans (Cheewasedtham 1990; Wardiatno 2004; Wardiatno and Mashar 2010). In our study, sex ratio showed that male is excessive than female in Bulungan District, North Kalimantan. The result of the present study agreed with other studies by Akter (2003), Ali et al (2004), Ikhwanuddin et al. (2010) and Musa et al. (2017). The dominance of males over females was proved to occur frequently in crab populations (Warburg et al. 2012). 


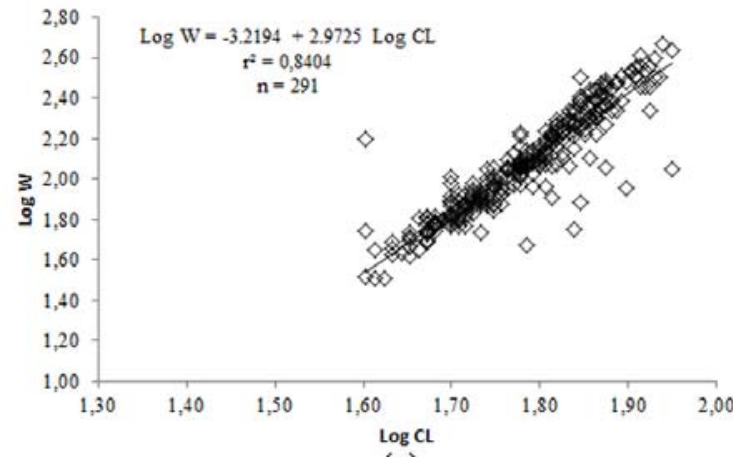

A

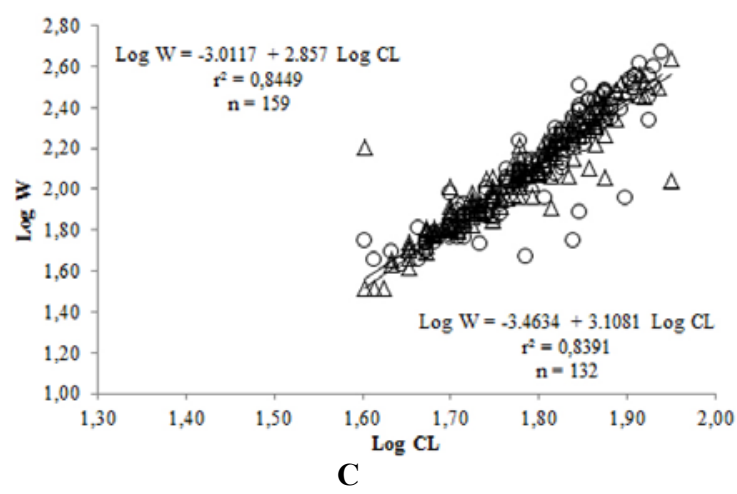

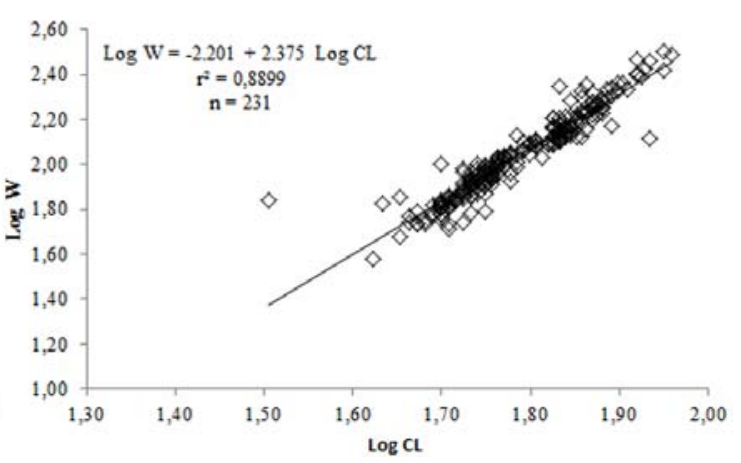

B

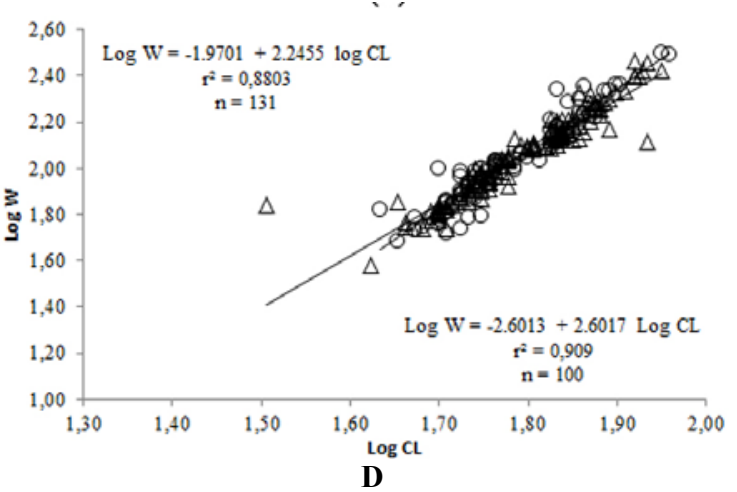

Figure 5. Carapace length (CL)-weight (W) relationship of Scylla serrata. (A) total male $\mathrm{n}=291$, (B) total female $\mathrm{n}=231$, (C) male, $\circ$ : Kahayan Delta $\mathrm{n}=159 ; \Delta$ : Tibi Island $\mathrm{n}=132(\mathrm{~d})$ female, $\circ$ : Kahayan Delta $\mathrm{n}=131 ; \Delta$ : Tibi Island $\mathrm{n}=100$

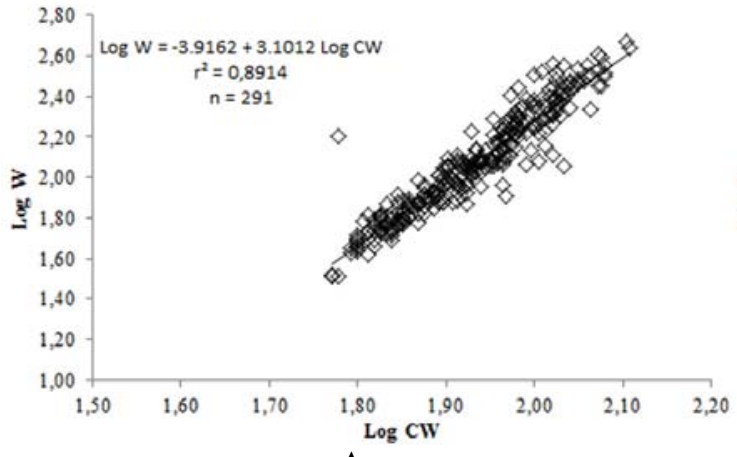

A

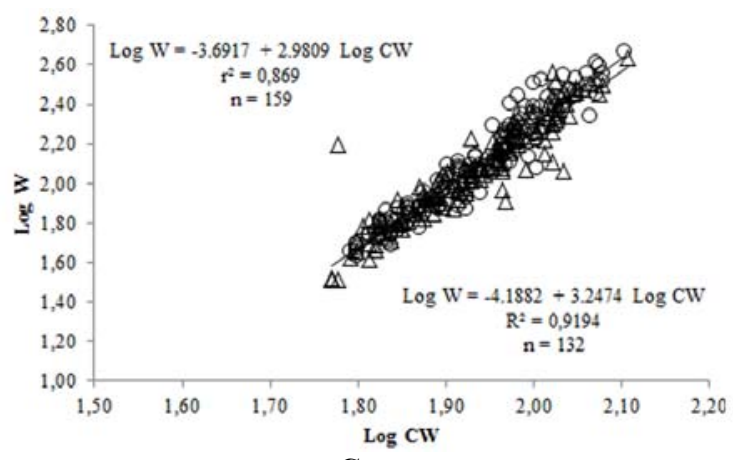

C
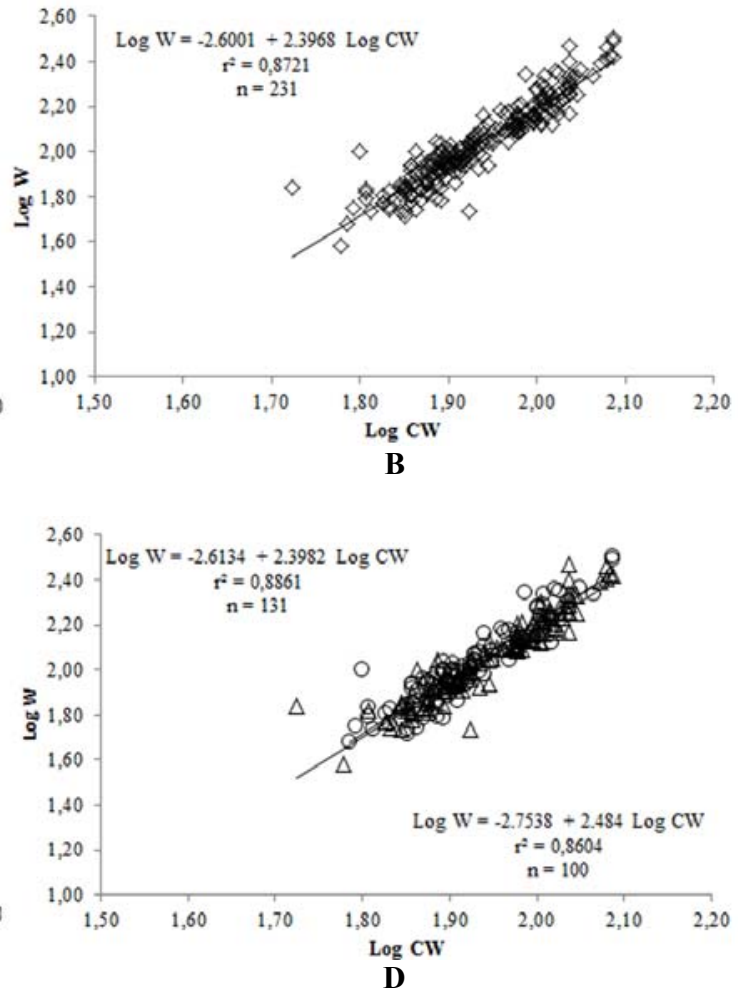

Figure 6. Carapace width (CW)-weight (W) relationship of Scylla serrata. (A) total male $\mathrm{n}=291(\mathrm{~B})$, total female $\mathrm{n}=231$, (C) male, $\circ$ : Kahayan Delta $\mathrm{n}=159 ; \Delta$ : Tibi Island $\mathrm{n}=132(\mathrm{~d})$ female, $\circ$ : Kahayan Delta $\mathrm{n}=131 ; \Delta$ : Tibi Island $\mathrm{n}=100$ 
Table 2. The growth coefficient values of Scylla serrata and S. tranquebarica in some locations.

\begin{tabular}{lllll}
\hline Species & Sex & Location & b value & Reference \\
\hline S. serrata & Male & Chilika Lagoon, India & 3.2150 & Mohapatra et al. (2010) \\
& Female & & 2.7510 & \\
Male & Inhace Island, Mozambique & 3.0244 & Toivio (2015) \\
& Female & & 2.4345 & \\
Male & Khulna region, Bangladesh & 3.0600 & Ali et al. (2004) \\
& Female & & 1.8928 & \\
Male & Bulungan district, Indonesia & 3.1012 & Present study \\
& Female & & 2.3968 & \\
S. tranquebarica & & & \\
& Male & Chilika Lagoon, India & 3.0060 & Mohapatra et al. (2010) \\
& Female & & & \\
& Male & Parangipettai coastal, India & 3.7820 & Thirunavukkarasu and Shanmugam (2011) \\
& Female & & 3.0202 & \\
\hline
\end{tabular}

In terms of size the crabs collected from Kahayan Delta was smaller than that from Tibi Island. This phenomenon might be caused by the discrepancies of habitat conditions in both locations (Tahmid et al. 2015a, 2015b). Similar result was also found in east Kutai (Wijaya et al. 2010), that have crabs size smaller than in mangrove habitat or the sea. In fishery point of view the smaller size may also be due to higher effort in capture fisheries (Sharpe and Hendry 2009).

The $b$ value of carapace width-weight relationship ranged from 2.3968 for female and 3.1012 for male. According Allen (1938), an ideal organism which maintains its shape throughout, the value of ' $b$ ' will be ' 3 '. But in few of organisms, the value of ' $b$ ' lies between 2.5 and 4.0 (Martin 1949). The $b$ value of male crab was higher than female crab. Higher $b$ value of male crabs was observed in other research of $S$. serrata in India (Mohapatra et al. 2010), Andaman Sea (Poovachiranon 1992), and Bengkulu (Herliany and Zamdial 2015). Other brachyuran species had estimated to have higher $b$ value in males than female (Josileen 2011; de Araújo and de Lira 2012). The male has the $b$ value more than 3 , but the female has the $b$ value less than 3 . This condition indicated the growth pattern is different for male and female. The growth pattern male is positive allometric and female is negative allometric. The growth is influenced by internal and external factors. Sex, age, nutrition and disease resistance include of internal factors, while water quality, predator, and habitat include of external factors (Effendie 1997; Levay and Walton 2007).

By comparing with some studies of $S$. serrata, the carapace width-weight relationship also showed similar results in the $b$ value. The $b$ value of male (more than 3 ) was higher than that of female (less than 3 ) (see Table 2). The similar results were found in some locations such as: India (Mohapatra et al. 2010), Mozambique (Toivio 2015), and Bangladesh (Ali et al. 2004). This biological character was also discovered in $S$. tranquebarica. The $b$ value of male in $S$. tranquebarica was higher than that in female in India (Mohapatra et al. 2010; Thirunavukkarasu and Shanmugam 2011). The relationship between carapace width and weight showed that the growth pattern indicated faster and larger in male. It is common phenomenon since the claws of male grows significantly larger than female in mud crabs. Pinheiro and Fiscarelli (2009) mentioned that bigger claw in male is enabled them to protect the females successfully during and after copulation. Pinheiro and Hattori (2006) revealed that females tend to reduce their chelae growth as they grow bigger, while males tend to do the opposite. Mature females utilize much of their energy into egg production and cause reducing their somatic growth (Pinheiro and Fransozo 2002; Ferkau and Fischer 2006).

Study of carapace width-weight relationship is important in fishery biology. If data of size frequency is available, it can be used to convert length to weight in order to estimate biomass (Effendie 1997; Froese 2006). In addition, it can be purposed for proper conservation and management of mud crabs (Ali et al. 2004).

In conclusion, the sex ratio of total collected samples (male to female) was 1:0.79. Crab size of Kahayan Delta was smaller than that of Tibi Island. The carapace lengthweight relationship of total samples showed logarithmic equations as follow: $\mathrm{W}=-3.2194+2.9725 \mathrm{Log} \mathrm{CL}$ for male and $\log \mathrm{W}=-2.2010+2.3750 \mathrm{Log} C \mathrm{~L}$ for female. While the carapace width-weight relationships are as follow: $\mathrm{W}=-3.9162+3.1012 \mathrm{Log} \mathrm{CW}$ for male and $\mathrm{Log}$ $\mathrm{W}=-2.6001+2.3968 \mathrm{Log} \mathrm{CW}$ for female. Based on the $\mathrm{b}$ values of carapace width-weight relationship, the growth pattern of male was positive allometric and female was negative allometric.

\section{ACKNOWLEDGEMENTS}

The research is a collaborative research between Bogor Agricultural University and University of Borneo Tarakan. The authors would like to thank reviewers for their constructive comments to improve the first version of manuscript. 


\section{REFERENCES}

Akter. 2003. Some aspect of biology and nutrition of Scylla serrata (Forskal, 1755) from South Western Region of Bangladesh. [Thesis]. Fisheries and Marine Resource Technology Discipline, Khulna University, Bangladesh. $26 \mathrm{p}$.

Allen KR. 1938. Some observations on the biology of the trout (Salmo trutta) in Widernere. J Anim Ecol 4: 264-273.

Ali MY, Kamal D, Hossain SMM, Azam MA, Sabbir W, Murshida A, Ahmed B, Azam K. 2004. Biology studies of the mud crab, Scylla serrate (Forskal) of the Sundarbans Mangrove Ecosystem in Khulna Region of Bangladesh. Pakistan J Biol Sci 7 (11): 1981-1987.

Atar HH, Sector S. 2003. Width/length-weight relationships of the blue crab (Callinectes sapidus Rathbun, 1896) population living in Beymelek lagoon lake. Turkish J Vet Anim Sci 27: 443-447.

Bagenal T. 1978. Method for assessment of fish production in fresh waters ( $3^{\text {rd }}$ ed.). Blackwell, Oxford.

Barnes DKA, Dulvy NK, Priestley SH, Darwall WRT, Choisel V, Whittington M. 2002. Fishery characteristics and abundance estimates of the mangrove crab Scylla serrata in southern Tanzania and northern Mocambique. S A J Mar Sci 24: 19-25.

Cheewasedtham C. 1990. Fishery biology of mud crab, Scylla serrata (Forskal) in Klong Ngao Mangrove Forest, Ranong Province. [Thesis]. Chulalongkorn University, Bangkok. [Thailand]

Cholik F. 2005. Review of mud crabs research culture in Indonesia. Central Research Institute for Fisheries, Jakarta.

de Araújo MSLC, de Lira JJPR. 2012. Condition factor and carapace width versus wet weight relationship in the swimming crab Callinectes danae Smith 1869 (Decapoda: Portunidae) at the Santa Cruz Channel, Pernambuco State, Brazil. Nauplius 20 (1): 41-50.

Effendie MI. 1997. Fishery Biology. Yayasan Pustaka Nusatama, Yogyakarta. [Indonesian]

Farizah N. 2011. Carateristic and morphology of mud crabs spermatozoa (Scylla olivacea, Herbest 1796). J Harpodon Borneo 4 (2): 44-50.

Ferkau C, Fischer K. 2006. Costs of reproduction in male Bicyclus anynana and Pieris napi butterflies: Effects of mating history and food limitation. Ethology 112 (11): 1117-1127.

Froese R. 2006. Cube law, condition factor and weight-length relationships: history, meta-analysis and recommendations. J Appl Ichthyol 22: 241-253.

Gayathre VL, Felix S, Durairaja R. 2016. Carapace width-weight relationship of mud crab Scylla serrata (Forskal, 1775) collected from Pulicat Lake, Tamilnadu, India. IRA-International J Appl Sci 5 (1): 29-33.

Gorce G, Erguden D, Sangun L, Cekic M, Alagoz S. 2006. Width/length and relationships of the blue crab (Callinectes sapidus Rathbum, 1986) population living in Camlik Lagoon Lake (Yumurtalik). Pakistan J Biol Sci 9 (8): 1460-1464.

Herliany NE, Zamdial. 2015. The relationship between the width of carapace and the weight of caught mangrove crab (Scylla spp.) in Kahyapu Village, Enggano Island, Bengkulu Province. Jurnal Kelautan 8 (2): 89-94.

Hill BJ. 1976. Natural food, foregut clearance-rate and activity of crab Scylla serrata. Mar Biol 34 (2): 109-116.

Ikhwanuddin M, Bachok Z, Hilmi MG, Azmie G, Zakaria MZ. 2010. Species diversity, carapace width-body weight relationship, size distribution and sex ratio of mud crab, genus Scylla from Setiu Wetlands of Terengganu coastal waters, Malaysia. J Sustain Sci Manag 5:97-109.

Iromo H, Fariza N, Amien M. 2013. Study the availability of mature broodstock mature ovari crab in Tarakan Island East Kalimantan. J Harpodon Borneo 6 (1): 57-63.

Iromo H, Farizah N. 2014. Analysis of thyroxine hormone content by Elisa method on female mangrove crab (Scylla serrata). J Harpodon Borneo 7 (1): 1-8.

Josileen J. 2011. Morphometrics and length-weight relationship in the blue swimmer crab, Portunus pelagicus (Linnaeus, 1758) (Decapoda Brachyura) from the Mandapam Coast, India. Crustaceana 84 (14): 1665-1681.

Keenan CP, Davie PJF, Mann DL. 1998. A revision of the genus Scylia de Haan, 1833 (Crustacea: Decapoda: Brachyura: Portunidae). Raffles Bull Zool 46 (1): 217-245.

Levay L, Walton ME. 2007. Population ecology of the mud crab Scylla paramamosain (Estampador) in an estuarine mangrove system; a mark recapture study. Mar Biol 151: 1127-1135.
Martin WR. 1949. The mechanics of environmental control of body form in fishes. University of Toronto Press, Toronto.

Mohapatra A, Mohanty RK, Mohanty SK, Dey S. 2010. Carapace width and weight relationships, condition factor, relative condition factor and gonado-somatic index (GSI) of mud crabs (Scylla spp.) from Chilika Lagoon, India. Indian J Mar Sci 39: 120-127.

Moutopoulos DK, Stergiou KI. 2002. Weight-length and length-length relationships for 40 fish species of the Aegean Sea (Hellas). J Appl Ichthyol 18: 200-203

Musa N, Manaf MTA, Saari NA, Hamzah M, Ibrahim WNW, Aznan AS, Zakaria K, Ghani SHA, Razzak LA, Musa N, Zainathan SC, Wahid MEA, Harrison FS, Ambak MA, Ikhwanuddin M, Ghaffar AMA. 2017. Some aspects of population biology of edible orange mud crab, Scylla olivacea (Herbst, 1796) during pre and post monsoon in Setiu Wetland, Terengganu, Malaysia. J Sustain Sci Manag 3: 42-52.

Natanael, Wiharyanto D. 2016. Potential resource of mangrove crab (Scylla sp.) traded in Tarakan City, North Kalimantan Province. J Harpodon Borneo 9 (1): 36-45.

Ng PKL. 1998. Crabs. In: Carpenter KE, Niem VH (eds.) FAO Species identification guide for fishery purposes. The living marine resources of the Western Central Pacific. Volume 2. Cephalopods, Crustaceans, Holothurians and Sharks. FAO, Rome.

Nirmale VH, Gangan SS, Yadav BM, Durgale P, Shinde KM. 2012. Traditional knowledge on mud crab; ethnoecology of Scylla serrata in Ratnagiri coast, Maharashtra. Indian J Trad Knowl 11 (2): 317-322.

Pinheiro MAA, Fiscarelli AG. 2009. Length-weight relationship and condition factor of the mangrove crab Ucides cordatus (Linnaeus, 1763) (Crustacea, Brachyura, Ucididae). Brazilian Arch Biol Technol 52 (2): 397-406.

Pinheiro MAA, Fransozo A. 2002. Reproduction of the speckled swimming crab Arenaeus cribrarius (Brachyura: portunidae) on the Brazilian coast near 23 degrees 30' S. J Crustacean Biol 22 (2): 416428.

Pinheiro MAA, Hattori GY. 2006. Relative growth of the mangrove crab Ucides cordatus (Linnaeus, 1763) (Crustacea, Brachyura, Ocypodidae) at Iguape, Sao Paulo, Brazil. Brazilian Arch Biol Technol 49 (5): 813-823.

Poovachiranon S. 1992. Biological studies of the mud crab Scylla serrata (Forskal) of the mangrove ecosystem in the Andaman Sea. In: Angell CA (eds). Report of the Seminar on Mud Crab Culture and Trade. FAO, Rome.

Ricker WE. 1975. Computation and interpretation of biological statistics of fish populations. J Fish Res Board Canada 191:203-233.

Sangun L, Tureli C, Akamca E, Duysak O. 2009. Width/length-weight and width/length relationships for $8 \mathrm{crab}$ species from northMediterranean coast of Turkey. J Anim Vet Adv 8 (1): 75-79.

Sharpe D, Hendry A. 2009. Life history change in commercially exploited fish stocks: an analysis of trends across studies. Evol Appl 2: 260275.

Steel RGD, Torrie JH. 1980. Principles and procedures of statistics. A biometrical approach. McGraw-Hill, New York. Thirunavukkarasu N, Shanmugam A. 2011. Length-weight and width-weight relationships of mud crab Scylla tranquebarica (Fabricius, 1798). Eur J Appl Sci 3 (2): 67-70.

Tahmid M, Fahrudin A, Wardiatno Y. 2015a. Habitat quality mud crab (Scylla serrata) in mangrove ecosystem of Bintan bay, Bintan District, Riau Islands. Jurnal Ilmu dan Teknologi Kelautan Tropis 7 (2): 535-551. [Indonesian]

Tahmid M, Fahrudin A, Wardiatno Y. 2015b. The assessment of size structure and population parameters of the mud crab (Scylla serrata) in mangrove ecosystem of Bintan bay, Riau Islands. Jurnal Biologi Tropis 15 (2): 93-104. [Indonesian]

Toivio S. 2015. Size, sex and distribution of Scylla serrata on Inhaca Island, Mozambique. [Thesis]. University of Gothenburg, Gothenburg, Sweden.

Triana S, Wiharyanto D. 2016. Study abundance meroplankton crabs Scylla sp. on different water conditions in the West Coast of Tarakan. J Harpodon Borneo 9 (2): 158-170.

Warburg MR., Davidson D, Yifrach H, Sayag L, Tichomirova Y. 2012. Changes in population structure and body dimensions of two xanthid crabs: A long-term study in a single boulder-shore. Arthropods 1: 4054

Wardiatno Y. 2004. Sex ratio in the population of the ghost shrimp, Nihonotrypaea japonica (Ortmann, 1891) (Decapoda: Thalassinidea: Callianassidae), collected from Shirakawa River, Central Part of 
Ariake Sound, Western Kyushu, Japan. Jurnal Ilmu-ilmu Perairan dan Perikanan Indonesia 11 (1): 39-43.

Wardiatno Y, Mashar A. 2010. Biological information on the mantis shrimp, Harpiosquilla raphidea (Fabricius 1798) (Stomatopoda, Crustacea) in Indonesia with a highlight of its reproductive aspects. J Trop Biol Conserv 7: 65-73.
Wijaya NI, Yulianda F, Boer M, Juwana S. 2010. Biology population of mud crab (Scylla serrata F.) at mangrove habitat of Kutai National Park, East Kutai Regency. J Oceanol Limnol Indonesia 36 (3): 443461. 